\title{
構造物の損壊に伴う不便益を考慮した ジオグリッド補強土壁のLCC算定法
}

\author{
大野孝二 ${ }^{1} \cdot$ 宮田喜壽 $2 \cdot$ 篠田昌弘 ${ }^{3} \cdot$ 小浪岳治 $^{4} \cdot$ 弘中淳市 $^{5}$
}

\begin{abstract}
構造物の損壊に伴う不便益を考慮したジオグリッド補強土壁のライフサイクルコスト（LCC）の計算法を提 案する. 提案法は, 初期建設費, 維持管理費, 地震による災害リスクの和でLCCを評価する. このうち災害リ スクは信頼性解析法で計算される破壊確率と，災害損失費の積と定義し，各損失費の標淮的な算定法を示した。 提案法に基づきジオグリッド補強土壁，L型擁壁，無補強盛土に対してLCCを計算した結果，ジオグリッド補 強土壁は交通量の大小や復旧区間の長さに関わらずLCCが最も小さいというアドバンテージを有することが明 らかになった．本文の内容は，IGS日本支部技術委員会第5ステージ（2010-2012）の成果の一部である.
\end{abstract}

キーワード : 補強土壁, ライフサイクルコスト, リスク, 不便益

\section{1. はじめに}

我が国の社会基盤は高度経済成長期に集中的に整備さ れた．それから約半世紀が経過し，多くの施設で維持管 理や更新の問題が顕在化するようになった. この課題を 克服するためには，調査から設計，施工，維持管理，そ して廃裹までにかかるコストを評価するライフサイクル コスト（LCC）を合理的に解析する方法を確立し，限ら れた予算の中で, 選択と集中により整備を行っていく必 要がある. 最近行われた総務省による行政評価・監視に 関する調查 ${ }^{1)}$ でも，LCC を考慮した社会基盤整備の重要 性が指摘されている.

LCC 解析の土木・建築分野での適用は，いくつかの方 面で既に始められ成果を挙げている．建築分野では事務 所ビル，学校，集合住宅を対象に，LCCの比較・検討が 可能な計算ソフトが開発され，実務で活用されている ${ }^{22}$. 橋梁分野では橋梁形式，橋長，幅員を入力するだけで簡 単に LCC を算定するソフトが開発され，実際の橋梁マ ネジメントに活用されている ${ }^{3)}$. しかし, 地盤分野, 特 にジオシンセティックス分野における LCC 解析法の確 立は遅れており, ソフト化のための基礎的検討と, 段階 的な実務への適用に関寸る検討が急務である.

上述の現状をふまえ，IGS 日本支部技術委員会第 4 久 テージ (2007-2009) では，ジオグリッド補強土壁，L 型 擁壁, 無補強盛土の LCC を共通の書式で評価可能な算 定法について検討し, 地震リスクを考慮した LCC 解析

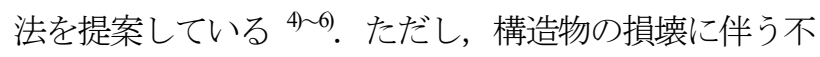

便益の考慮は今後の課題とされ，LCCの評価に社会基盤 の重要度を考慮することはできなかった，そこで IGS 日 本支部技術委員会第5 ステージ (2010-2012) では，ジオ グリッド補強土構造物の環境負荷の評価法について検討 する一方で，変状事例の分析に基づいたジオグリッド補 強土構造物のライフサイクルのシナリオについて検討し たうえで, 先に提案した LCC の評価法を拡張した. 本 文では，構造物の損壊に伴う不便益を考慮したジオグリ ッドの LCC 算定法について説明し，代表的な設計条件 に対する試算結果を示して，ジオグリッド補強土壁は L 型擁壁や無補強盛士に対し, 構造物の損壊に伴う不便益 を考慮したライフサイクルコストの面においても大きな アドバンテージを有することを示す.

\section{2. ジオグリッド補強土壁のLCC算定法}

\section{(1) 本研究の基本的な考え}

本文ではライフサイクルコスト（LCC）を次式で評価 する方法を提示する.

$$
L C C=C+M+R
$$

ここで, $C$ : 初期建設費, $M$ : 維持管理費であり, $R$ : 災害リスクは設計耐用年数における破壊確率 : $P_{\mathrm{f}}$ と災害 損失費 $: R_{\mathrm{f}}$ を用いて次式で表される.

$$
R=P_{\mathrm{f}} \cdot R_{\mathrm{f}}
$$

上記の方法では, $C, M, R_{\mathrm{f}}, P_{\mathrm{f}}$ の 4 つの評価が必要に なる.このうち, 前者 $2 つ の$ 費用に関する標淮的算定法

\footnotetext{
1正会員，飛島建設＼cjkstart建設事業本部 土木事業統括部（二213-0012 川崎市高津区坂戸3-2-1）

2正会員, 防衛大学校 建設環境工学科（广239-8686 横須賀市走水1-10-20）

3正会員，鉄道総合技術研究所 研究開発推進室（干185-8540 東京都国分寺市光町2-8-38)

4正会員，岡三リビック 技術部（干108-0023 東京都港区芝浦4-16-23）

5正会員，三井化学産資 環境資材開発部（二113-0034 東京都文京区湯島3-39-10）
} 


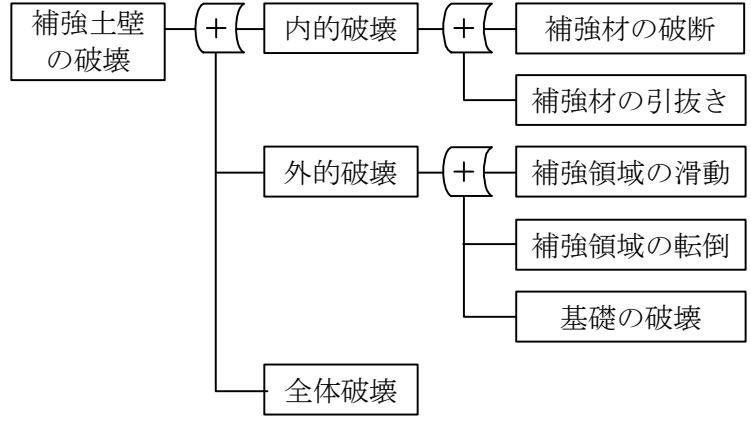

図-1ジオグリッド補強土壁の破壊モード

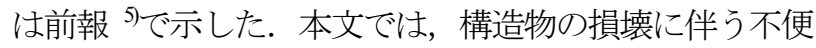
益を考慮した $L C C$ の評価法を確立寸るための $R_{\mathrm{f}}$ の算定 法を次節以降で議論する.

$P_{\mathrm{f}}$ の算定には，図-1 に示すような複数の破壊モード を考え, 各破壊モードの生起確率 : $P\left(\mathrm{E}_{\mathrm{j}}\right)$ を FORM (First Order Reliability Method)で計算し, 最終的に次式で $P_{\mathrm{f}}$ を計 算する方法を用いた ${ }^{\text {t }}$.

$$
P_{f}=1-\prod_{i=1}^{m}\left\{1-P\left(E_{\mathrm{i}}\right)\right\}
$$

ここで，П：積確率の演算子である，上式で計算される 破壊確率は理論的に 1 次の上限值に位置づけられる。計 算の詳細については，文末の付録を参照されたい，特筆 すべきは，ジオグリッド補強土壁の内的破壊の生起確 率 : $P\left(\mathrm{E}_{\mathrm{int}}\right)$ の算定において，1層のジオシンセティック スが分担する補強領域を構造要素と定義し, 各構造要素 の複合的な破壊が全体破壊につながるという考えに基づ き，システム午長性を考慮した破壊確率の算定法を用い ていることである.

\section{（2）災害損失費の算定法}

前報では, 災害損失費 $: R_{\mathrm{f}}$ を次式で算定する方法を示 した ${ }^{4,5)}$.

$$
R_{\mathrm{f}}=R_{\text {reset }}+R_{\text {recon }}
$$

ここで， $R_{\mathrm{reset}}$ : 解体撤去費, $R_{\mathrm{recon}}$ : 再構築費である. 本

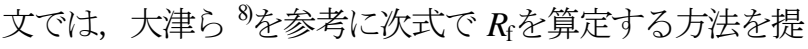
示する.

$$
R_{\mathrm{f}}=R_{\mathrm{reset}}+R_{\mathrm{recon}}+R_{\mathrm{jam}}+R_{\mathrm{det}}+R_{\mathrm{ppl}}
$$

ここで, $R_{\mathrm{jam}}$ : 道路損壊に伴う時間損失費, $R_{\mathrm{det}}$ : 復旧中 に迂回路を走行することで生じる走行損失費， $R_{\mathrm{ppl}}$ ：損 壊に伴う人的損失費である. $R_{\text {rext }}$ と $R_{\text {reom }}$ の算定法につい ては前報 5)で説明しているので，残り 3 つの方法につい て以下に説明する。

$R_{\mathrm{jm}}$ については時間価值原単位を用いる方法, $R_{\mathrm{det}}$ につ いては走行費用原単価を用いる方法で算定する ${ }^{9}$ ．この 場合，両費用の算定式は以下のとおり表される.

$$
\begin{gathered}
R_{\text {jam }}=\Delta t_{\mathrm{d}} \sum\left(A_{\mathrm{m}} N_{\mathrm{m}} \Delta t_{\mathrm{h}}\right) \\
R_{\text {det }}=\Delta t_{\mathrm{d}} \sum N_{\mathrm{m}}\left(B_{\mathrm{m}}^{\mathrm{L}} \Delta r^{\mathrm{L}}-B_{\mathrm{m}}^{\mathrm{H}} \Delta r^{\mathrm{H}}\right)
\end{gathered}
$$

\begin{tabular}{|c|c|c|c|c|}
\hline & $\mathrm{H}(\mathrm{m})$ & $\begin{array}{c}\text { 初期建設費: } \\
C(\text { yen } / \mathrm{m}) \\
\end{array}$ & $\begin{array}{c}\text { 維持管理費: } \\
M(\text { yen } / \mathrm{m})\end{array}$ & $\begin{array}{l}\text { 災害復旧費: } \\
R_{\text {recorr }} \text { (yen/m) }\end{array}$ \\
\hline \multirow{3}{*}{ 補強土壁 } & 6.0 & 381,000 & \multirow{9}{*}{$\begin{array}{c}12,000 \\
\text { (yen/m) } \\
\times \text { 供用年数 }\end{array}$} & 283,000 \\
\hline & 8.0 & 491,000 & & 416,000 \\
\hline & 10.0 & 623,000 & & 574,000 \\
\hline \multirow{3}{*}{ L型擁壁 } & 6.0 & 408,000 & & 407,000 \\
\hline & 8.0 & 596,000 & & 705,000 \\
\hline & 10.0 & 780,000 & & $1,012,000$ \\
\hline \multirow{3}{*}{ 盛士 } & 6.0 & 377,000 & & 163,000 \\
\hline & 8.0 & 442,000 & & 226,000 \\
\hline & 10.0 & 507,000 & & 298,000 \\
\hline
\end{tabular}

表-1 初期建設費・維持管理費・災害復旧費の算定結果 ${ }^{5}$

表-2 解析厅ース

\begin{tabular}{|c|c|c|}
\hline & $\begin{array}{c}\text { 条件 } \mathrm{A}: \text { 構造物の } \\
\text { 延長 }=30 \mathrm{~m}\end{array}$ & $\begin{array}{c}\text { 条件 } \mathrm{B}: \text { 構造物 } \\
\text { の延長 }=50 \mathrm{~m}\end{array}$ \\
\hline $\begin{array}{c}\text { 条件 } 1: \text { 交流量・大 } \\
(1000 \text { 台/日レベル }\end{array}$ & 条件 $1-\mathrm{A}$ & 条件 $1-\mathrm{B}$ \\
\hline $\begin{array}{c}\text { 条件 } 2: \text { 交流量・小 } \\
(2000 \text { 台/日レベル })\end{array}$ & 条件 $2-\mathrm{A}$ & 条件 $2-\mathrm{B}$ \\
\hline
\end{tabular}

ここで， $\Delta t_{\mathrm{d}}$ : 通行止め日数 $($ 日 $), \mathrm{m}$ : 車種 $(\mathrm{m}=1$; 乗 用車, $\mathrm{m}=2$; バス, $\mathrm{m}=3$; 小型貨物車, $\mathrm{m}=4$; 普通貨物 車）， $A_{\mathrm{m}}$ ：時間価值原単位（円/台・分）， $N_{\mathrm{m}}$ ：日交通 量（台/日）， $\Delta_{\mathrm{h}_{\mathrm{h}}}$ : 1 日あたりの損失時間（分）, $B_{\mathrm{m}}{ }^{\mathrm{L}}$ : 迁回路における走行費用原単価 (円/台· $\mathrm{km}$ ) $\Delta r^{\mathrm{L}}$ : 迂回 路走行距離 $(\mathrm{km}) ， B_{\mathrm{m}}{ }^{\mathrm{H}}$ : 現道における走行費用原単価 $($ 円台 $\cdot \mathrm{km}) \Delta \Delta^{\mathrm{H}}$ : 現道走行距離 $(\mathrm{km})$.

$R_{\mathrm{ppl}}$ については，道路損壊に巻き込まれた車輛の搭乗 者の死傷率をもとに算定した死傷者数 : $N_{\mathrm{n}}$ に, 死傷者 1 人当たりの損失額 : $C_{\mathrm{n}}$ を乗じて算定する ${ }^{10}$.

$$
R_{\mathrm{ppl}}=\sum\left(C_{\mathrm{n}} N_{\mathrm{n}}\right)
$$

ここで, $\mathrm{n}$ : 人的損失のレベル $(\mathrm{n}=1 ;$ 死亡, $\mathrm{n}=2$; 重傷, $\mathrm{n}=3$; 軽傷）。次章では，ジオグリッド補強土壁，L 型 擁壁，盛土を対象に，LCCのより具体的な算定方法とそ れによる計算結果を提示し，ジオグリッド補強土壁の優 位性について考察する.

\section{3. 解析結果と考察}

\section{(1) 計算条件}

補強土壁， $\mathrm{L}$ 型擁壁，盛土を対象に，構造物の高さ $\mathrm{H}$ $=6.0,8.0,10.0 \mathrm{~m}$ の 3 条件に対して LCC の算定を行った. 計算対象は，以下の条件を仮定した場合に，既存の設計

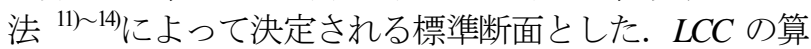
定対象とした設計断面の例を図-2に示寸.

【盛士材】単位重量 : $\gamma=19.0 \mathrm{kN} / \mathrm{m}^{3}$, 粘着力 : $c=0 \mathrm{kN} / \mathrm{m}^{2}$, 内部摩擦角 : $\phi=30^{\circ}$

【必要安全率】常時 : $F_{\mathrm{s}}=1.2$, 地震時 : $F_{\mathrm{s}}=1.0$

【設計水平震度】 $k_{\mathrm{h}}=0.20$

【設計耐用年数】 40 年間 


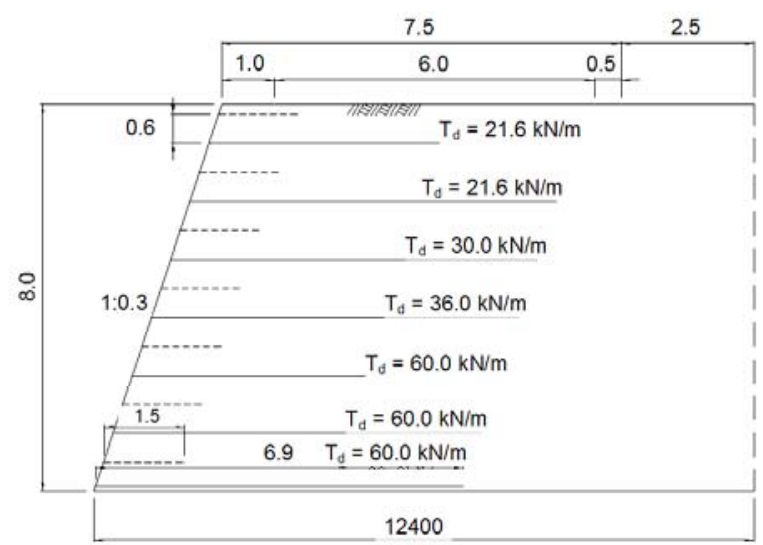

(a) ジオグリッド補強土壁

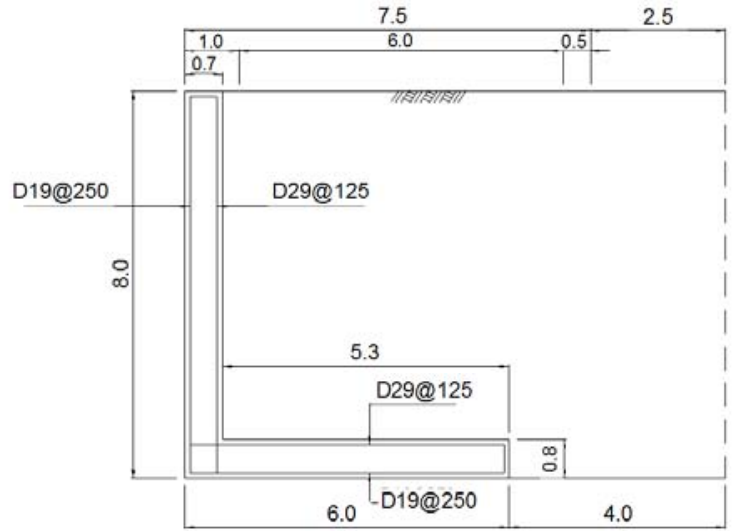

(b) L 型擁壁

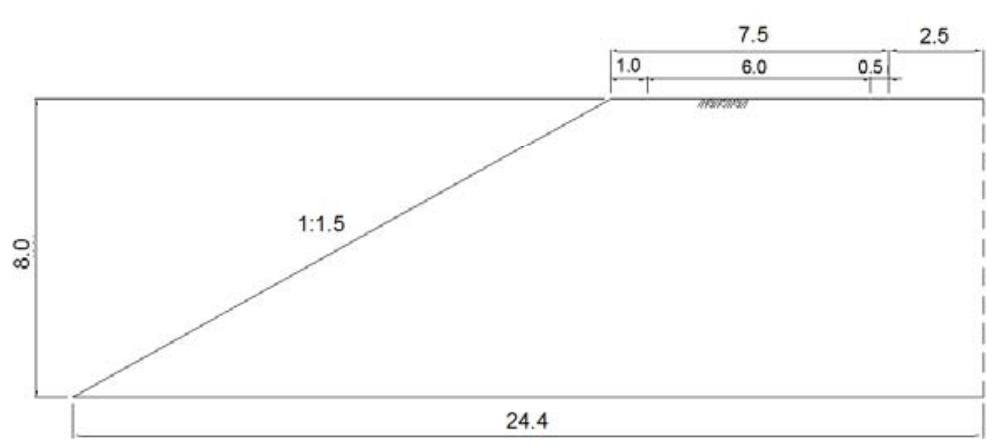

(c) 盛土（無補強）
図中・長さの単位: $m$

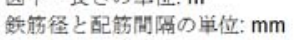

図-2 LCC 解析の対象とした設計断面 $(\mathrm{H}=8.0 \mathrm{~m})$

表 -3 復旧必要日数と通行止め日数

\begin{tabular}{|c|c|c|c|c|c|c|c|}
\hline \multirow{2}{*}{\multicolumn{2}{|c|}{$\begin{array}{c}\text { 施工延長 } \\
\text { 構造物の壁高 }\end{array}$}} & \multicolumn{3}{|c|}{$30 \mathrm{~m}$} & \multicolumn{3}{|c|}{$50 \mathrm{~m}$} \\
\hline & & \multirow{2}{*}{$\frac{6 \mathrm{~m}}{18}$} & \multirow{2}{*}{$\frac{8 m}{25}$} & \multirow{2}{*}{$\frac{10 m}{34}$} & \multirow{2}{*}{$6 \mathrm{~m}$} & \multirow{2}{*}{$\begin{array}{l}8 \mathrm{~m} \\
39 \\
\end{array}$} & \multirow{2}{*}{$\frac{10 \mathrm{~m}}{54}$} \\
\hline 補強 & 復旧必要日数 & & & & & & \\
\hline 土壁 & 通行止め日 & 23 & & 43 & 34 & 49 & 68 \\
\hline \multirow{2}{*}{$\begin{array}{l}\text { L型 } \\
\text { 擁壁 } \\
\end{array}$} & 復旧必要日数 & 2 & & 56 & 34 & 5 & 64 \\
\hline & 通行止め日数 & 35 & 5 & 70 & 43 & 6 & 80 \\
\hline \multirow{2}{*}{ 盛土 } & 復旧必要日数 & 14 & & 2. & 2 & 2 & 33 \\
\hline & 通行止め日数 & 18 & 22 & 28 & 27 & 33 & 42 \\
\hline
\end{tabular}

\#通行止め日数 $=$ 復旧必要日数 $/ 0.8$

また，ジオグリッド補強土壁の破壊確率 : $P_{\mathrm{f}}$ の計算に おいては, 盛土材の強度定数の変動係数 $10 \%$, 補強材 の引張強度の変動係数 $5 \%$, 水平震度の変動係数 $50 \%$ を 仮定した ${ }^{15}$. この変動係数には仮定する設計耐用年数と 地震規模に対する地震の生起確率も考慮されている.

LCC の計算に用いた初期建設費, 維持管理費, 解体・ 撤去費, 再構築費を表-1 に示す ${ }^{5}$. 構造物の損壊に伴う 不便益を考慮した LCC は交通量の大小と損壊範囲によ って変化する. 本研究においては，表-2 に示す 4 条件 についてLCCを算定した.

\section{(2) 時間損失費の算定}

式(6)を用いて時間損失費を計算するにあたって，ま
ず 1 日あたりの損失時間 : $\Delta \Delta_{\mathrm{h}}$ を設定した. 今回の計算 においては, 迂回路走行距離 : $\Delta r^{\mathrm{L}}$ は現道走行距離 : $\Delta r^{\mathrm{H}}$ の 1.5 倍という条件を仮定し, $\Delta t_{\mathrm{h}}=\left(\Delta r^{\mathrm{L}}-\Delta r^{\mathrm{H}}\right) /$ 迂回路の 走行速度（今回は $35 \mathrm{~km} / \mathrm{h}$ ) より $\Delta_{\mathrm{h}}$ を設定した.

次に通行止め日数 : $\Delta t_{\mathrm{d}}$ を設定した. 今回の計算にお いては，補強土壁，L型擁壁，盛土について崩壊した土 構造物を同じ条件で再構築する場合を想定し，作業のク リティカルパスを描いて必要工事日数を見積もり，それ を天候不順による作業不能日のみを考慮した稼働率 0.8 を考慮して $\Delta t_{\mathrm{d}}$ を設定した. クリティカルパスの検討結 果の例として，構造物の高さ $10 \mathrm{~m}$ ，施工延長 $50 \mathrm{~m}$ に対 する結果を図-3に示す。ここで，補強土壁，L型擁壁， 盛土の再構築に必要な工事日数の算定は, 土木工事標準 積算基準書 ${ }^{10}$ に示されている標準施工量や日当たり施工 量をもとに算出した。一日当たりの作業時間については, 緊急災害復旧工事を仮定して，昼 8:00〜 17:00，夜 18:00 〜26:00 の 2 交代制を仮定した. 以上の考えに基づき算 定した復旧必要日数と通行止め日数 : $\Delta t_{\mathrm{d}}$ のまとめを表3 に示寸. 盛土は復旧日数が最も短く, L 型擁壁は, 損 壊した躯体の解体・撤去に時間を要することと，再構築 時においてコンクリートのひび割れに配慮して躯体を分 割して施工寸ることから，他の 2 つ構造形式と比較し て復旧に要する日数が長くなる結果となった. ジオグリ ッド補強土壁の復旧日数は, いずれの構造物の高さにお いても，盛土と L 型擁壁の間になった. 


\begin{tabular}{|c|c|c|c|c|c|c|c|c|c|c|c|c|c|c|c|c|c|c|c|c|c|c|c|c|c|c|c|}
\hline \multirow{3}{*}{$\begin{array}{c}\text { 工種 } \\
\text { 盛监延長 } 50 \mathrm{~m}\end{array}$} & \multirow{3}{*}{ 単 } & \multirow{3}{*}{\begin{tabular}{|l} 
概筧 \\
数量
\end{tabular}} & \multicolumn{10}{|c|}{ 1分月 } & \multicolumn{12}{|c|}{ 2ヶ月 } & \multicolumn{3}{|c|}{ 3ヶ月 } \\
\hline & & & \begin{tabular}{l|l|}
2 & 4 \\
\end{tabular} & & \begin{tabular}{|l|l|}
10 \\
\end{tabular} & \begin{tabular}{|l|l|}
12 & 14 \\
\end{tabular} & \begin{tabular}{|l|l|}
16 \\
\end{tabular} & \begin{tabular}{|l|l|}
18 & 20 \\
\end{tabular} & \begin{tabular}{|l|l|}
0 & 22 \\
\end{tabular} & 24 & \begin{tabular}{|l|l|}
26 & 28 \\
\end{tabular} & & 2 & 4 & \begin{tabular}{c|c|}
6 & 8 \\
\end{tabular} & \begin{tabular}{|l|l|}
8 & 10 \\
\end{tabular} & 12 & & & & 20 & \begin{tabular}{|l|l|}
22 & 24 \\
\end{tabular} & $26 \mid$ & \begin{tabular}{|l|l|}
28 & 30 \\
\end{tabular} & & & \begin{tabular}{|l|l|}
8 & 10 \\
\end{tabular} \\
\hline & & & \begin{tabular}{|l|l|}
2 & 4 \\
\end{tabular} & \begin{tabular}{|l|l|}
6 & 8 \\
\end{tabular} & 10 & \begin{tabular}{|l|l|}
12 & 14 \\
\end{tabular} & \begin{tabular}{|l|}
16 \\
\end{tabular} & \begin{tabular}{|l|l|}
18 & 20 \\
\end{tabular} & \begin{tabular}{|l|l|}
0 & 22 \\
\end{tabular} & 24 & \begin{tabular}{|l|l|}
26 & 28 \\
\end{tabular} & & 32 & 34 & \begin{tabular}{|l|l|}
36 & 38 \\
\end{tabular} & \begin{tabular}{|l|l|}
8 & 40 \\
\end{tabular} & 42 & 44 & \begin{tabular}{ll|}
46 \\
\end{tabular} & 48 & 50 & \begin{tabular}{|l|l|}
52 & 54 \\
\end{tabular} & \begin{tabular}{|l|}
56 \\
\end{tabular} & \begin{tabular}{|l|l|}
58 & 60 \\
\end{tabular} & \begin{tabular}{|l|l|}
62 & 64 \\
\end{tabular} & \begin{tabular}{|l|l|l|}
6 & 66 \\
\end{tabular} & \begin{tabular}{l|l|}
68 & 70 \\
\end{tabular} \\
\hline 淮備工 & 式 & & 1 & $110 \mathrm{~m}$ & 1 & 11 & 1 & & & & & & & $!$ & & & & & & & & & & & & 1 & \\
\hline 排土工(整地を含き) & $\mathrm{m}^{3}$ & 9,500 & $\mathbf{v}$ & (7"ll2 & 20t級 $\times$ & $\times 1, \mathrm{BHO}$. & $.8 \mathrm{~m}^{3} \times 2$ & & & & & & & & 搬距離1 & 淮1 & & & & & & $\rightarrow$ : & לテン & 价ルパ & & & \\
\hline & & & & & & & & & $\begin{array}{l}540 m^{3} \\
\left(7^{\prime} l 115\right.\end{array}$ & 5t級 $\times$ & 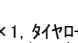 & & & $\mathrm{D}$ & IDなし & & & & & & & 作業は緊 & & 㫫考膚し & て2交代制 & 玮を孝虜 & \\
\hline 盛土工 & $\mathrm{m}^{3}$ & 9,500 & & & & & & & (N)15 & & 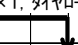 & & & i & & & & & & & & 荤: $: 8: 00$ & 㛣は & 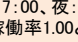 & 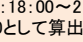 & & \\
\hline 舒装工 & $\mathrm{m}^{2}$ & 375 & & & & & & & & & & & & $!$ & & & & & & & & & & & & & \\
\hline 付带設備工 & 式 & 1 & & & & & & & & & & & & I & & & & & & & & & & & & & \\
\hline 後片付け & 式 & 1 & & & & & & & & & & & & : & & & & & & & & & & & & & \\
\hline & & & & & & & & & & & & & & $i$ & & & & & & & & & & & & & \\
\hline & & & & & & & & & & & & & & I & & & & & & & & & & & & & \\
\hline & & & & & & & & & & & & & & $!$ & & & & & & & & & & & & & \\
\hline & & & & & & & & & & & & & & ! & & & & & & & & & & & & & \\
\hline
\end{tabular}

(a) 盛土（条件 $2-\mathrm{B}$ )

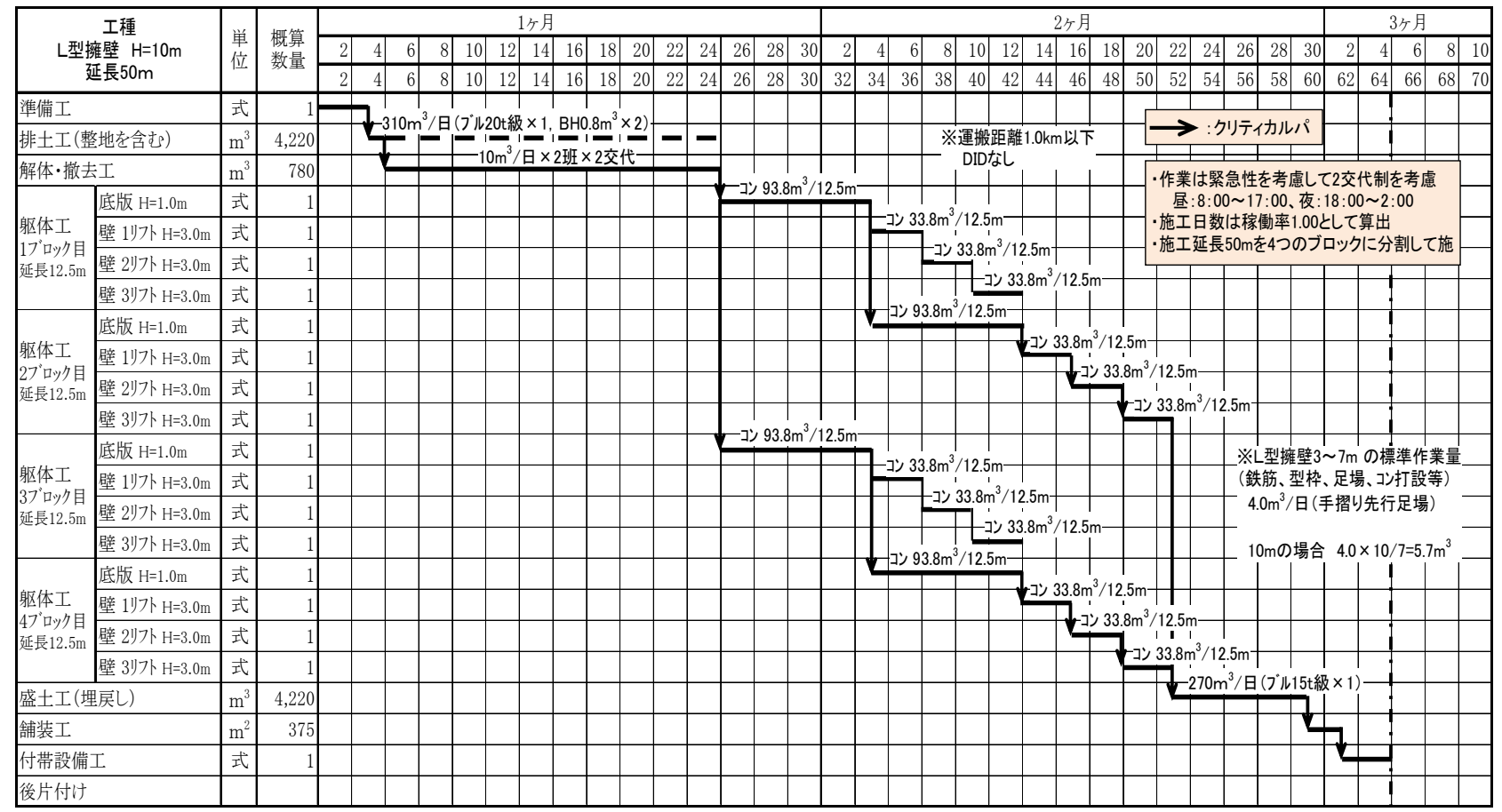

(b) L型擁壁 (条件 2-B)

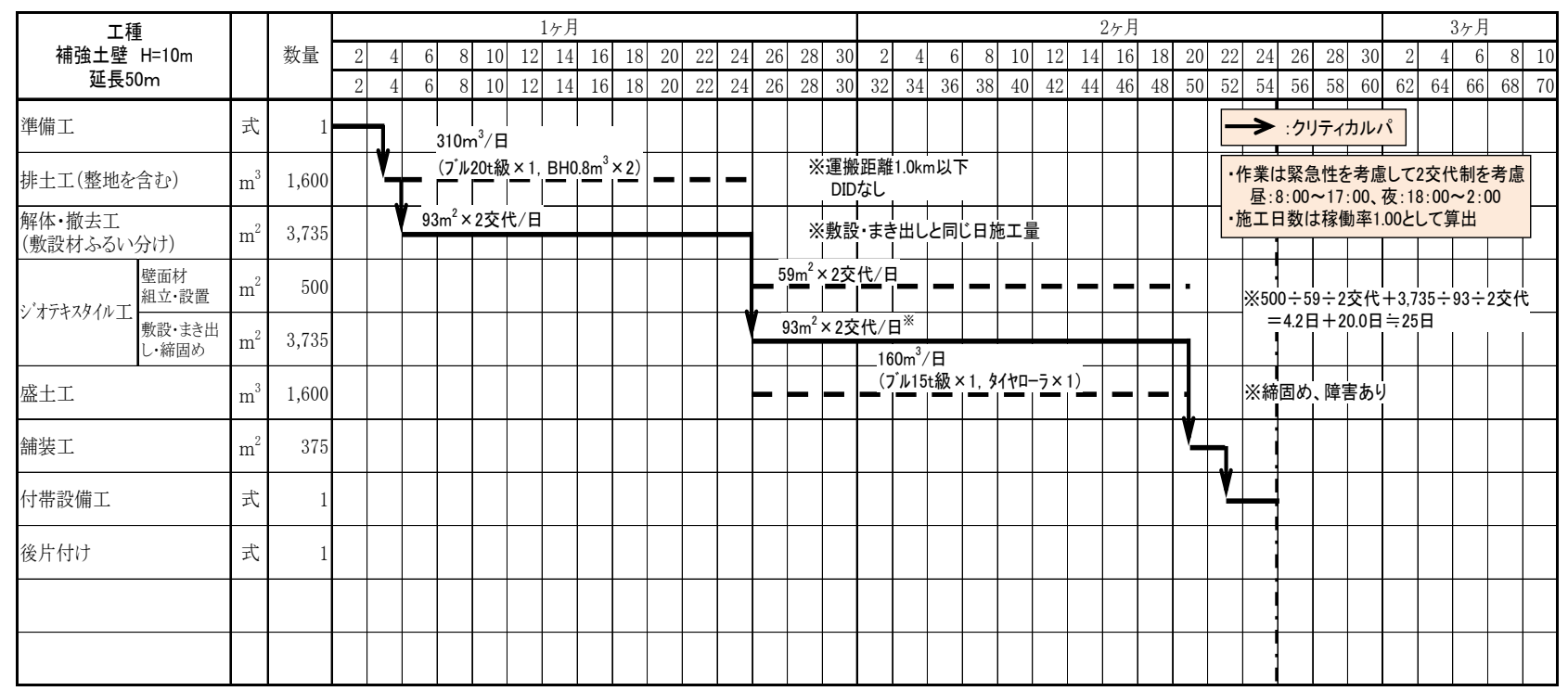

（c）補強土壁 (条件 $2-\mathrm{B})$

図-3 構造物の延長 $50 \mathrm{~m}$ の場合の復旧日数の算定 
表-4 車種別の時間価值原単位 ${ }^{9}$

\begin{tabular}{|l|c|}
\hline 車種 & 時間価值原単位(円/分·台) \\
\hline 乗用車 & 40.10 \\
\hline バス & 374.27 \\
\hline 小型貨物車 & 47.91 \\
\hline 普通貨物車 & 64.18 \\
\hline
\end{tabular}

表-5 想定した車種別の日交通量 ${ }^{17}$

\begin{tabular}{|l|l|c|c|}
\hline \multicolumn{2}{|l|}{} & 条件 1 & 条件 2 \\
\hline \multicolumn{2}{|l|}{ 区間長 } & $10.2 \mathrm{~km}$ & $11.7 \mathrm{~km}$ \\
\hline \multicolumn{2}{|l|}{ 旅行速度 } \\
\hline \multirow{2}{*}{$\begin{array}{l}\text { 日交通量 } \\
\text { (台/日) }\end{array}$} & 乗用車 & $48.3 \mathrm{~km} / \mathrm{h}$ & $45.4 \mathrm{~km} / \mathrm{h}$ \\
\cline { 2 - 4 } & バス & 10,117 & 1,617 \\
\cline { 2 - 4 } & 小型貨物車 & 2,676 & 53 \\
\cline { 2 - 4 } & 普通貨物車 & 1,827 & 458 \\
\cline { 2 - 4 } & 合計 & 14,724 & 149 \\
\hline
\end{tabular}

\#1 : 福井市宿布町における国道 158 号での交通調査結果に基づ

く. \#2 : 福井市大味町における国道 305 号での交通調査結果に 基づく.

表-6 車種別の走行経費原単位 ${ }^{17)}$

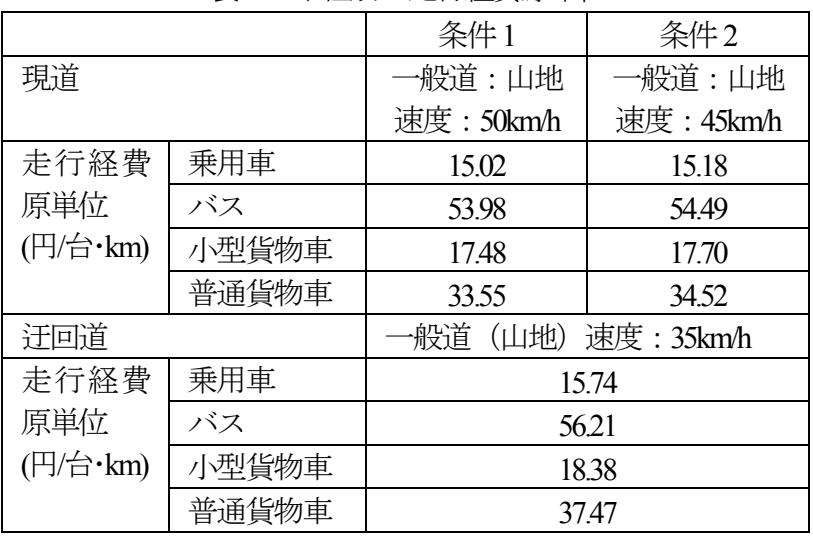

以上の情報に，車種別時間価值原単位： $A_{\mathrm{m}}$ と日交通 量（台/日）: $N_{\mathrm{m}}$ を加味して時間損失費を計算した。こ こで， $A_{\mathrm{m}}$ は国土交通省の費用便益分析マニュアルに基 づき表-4 に示す值を用いた ${ }^{9)}$. $N_{\mathrm{m}}$ は福井県が平成 17 年 度に実施した一般交通量調査報告書をもとに，表一5に 示す值を用いた ${ }^{17)}$.

\section{(3) 走行損失費の算定}

式(7)を用いて走行損失費を計算するにあたって，迂 回路における走行費用原単価（円/台· $\mathrm{km}$ ） : $B_{\mathrm{m}}{ }^{\mathrm{L}}$, 迁回 路走行距離 $(\mathrm{km}): \Delta r^{\mathrm{L}}$ ，現道における走行費用原単価 $($ 円 $/$ 台 $\cdot \mathrm{km}): B_{\mathrm{m}}{ }^{\mathrm{H}}$, 現道走行距離 $(\mathrm{km}): \Delta r^{\mathrm{H}}$ を設定 寸る必要がある. 本研究では, 先に示したように $\Delta^{\mathrm{L}}$ $\Delta r^{\mathrm{H}}$ の 1.5 倍という条件を仮定した. $B_{\mathrm{m}}{ }^{\mathrm{L}}$ と $B_{\mathrm{m}}{ }^{\mathrm{H}}$ について は, 福井県が平成 17 年度に実施した一般交通量調査 ${ }^{17}$ をもとに，表一に示値を用いた。

\section{(4) 人的損失費の算定}

式(8)を用いて人的損失費を計算するにあたって，死 傷者一人あたりの損失額 : $C_{\mathrm{n}}$ を設定する必要がある.
表-7 死傷者一人あたりの損失額 ${ }^{18)}$

\begin{tabular}{|l|c|c|c|}
\hline & 死亡 & 重傷 & 軽傷 \\
\hline 金銭的損失(千円) & 32,774 & 9,259 & 1,378 \\
\hline 非金銭的損失(千円) & 212,900 & 0 & 0 \\
\hline 合計(千円) & 245,674 & 9,259 & 1,378 \\
\hline
\end{tabular}

表-8 人的損失額に対する算定結果

(a) 条件 1-A, 1-Bに対して

\begin{tabular}{|c|c|c|c|c|}
\hline & レベル & 推定人数 & 損失額(千円) & 合計(千円) \\
\hline \multirow{3}{*}{$\begin{array}{l}\text { 延長 } \\
30 \mathrm{~m}\end{array}$} & 死亡 & 0.03 & 7,370 & \multirow{3}{*}{8,146} \\
\hline & 重傷 & 0.06 & 556 & \\
\hline & 軽傷 & 0.16 & 220 & \\
\hline \multirow{3}{*}{$\begin{array}{l}\text { 延長 } \\
50 \mathrm{~m}\end{array}$} & 死亡 & 0.04 & 9,827 & \multirow{3}{*}{10,857} \\
\hline & 重傷 & 0.08 & 741 & \\
\hline & 軽傷 & 0.21 & 289 & \\
\hline
\end{tabular}

(b) 条件 2-A，2-Bに対して

\begin{tabular}{|c|c|c|c|c|}
\hline & レベル & 推定人数 & 損失額(千円) & 合計(千円) \\
\hline \multirow{3}{*}{$\begin{array}{l}\text { 延長 } \\
30 \mathrm{~m}\end{array}$} & 死亡 & 0.00 & 0 & \multirow{3}{*}{134} \\
\hline & 重傷 & 0.01 & 93 & \\
\hline & 軽傷 & 0.03 & 41 & \\
\hline \multirow{3}{*}{$\begin{array}{l}\text { 延長 } \\
50 \mathrm{~m}\end{array}$} & 死亡 & 0.01 & 2,457 & \multirow{3}{*}{2,591} \\
\hline & 重傷 & 0.01 & 93 & \\
\hline & 軽傷 & 0.03 & 41 & \\
\hline
\end{tabular}

本研究では，国土交通省より示された表-7 に示寸值を 用いて計算した ${ }^{18)}$. 従来の金銭的損失に加えて，死亡に 伴う精神的損失を考慮した非金銭的損失の 2 つ損失を考 慮する点に特徵がある.

もうひとつの条件である死傷者 : $N_{\mathrm{n}}$ の設定について は次式を用いた。

$$
N_{\mathrm{n}}=N_{\mathrm{a}} N_{\mathrm{p}} R_{\mathrm{t}}
$$

ここで, $N_{\mathrm{a}}$ : 自動車事故台数, $N_{\mathrm{p}}$ : 平均乗車人数, $R_{\mathrm{t}}$ : 死傷者率.

$N_{\mathrm{a}}$ については, $N_{\mathrm{a}}=$ 被害箇所 $\times($ 道路延長十自動車停 止距離) $\times$ 単位距離あたりの交通量で評価する方法を用 いた ${ }^{10)}$. 今回の計算において，被害箇所 $=1$ とし，道路 延長は表-2 に示した構造物の延長距離, 自動車停止距 離は日本交通安全協会が示した普通車の速度 $20 ， 40$,

$60,80 \mathrm{~km} / \mathrm{h}$ における各停止距離の平均值 $38 \mathrm{~m}$ とした ${ }^{19}$. $N_{\mathrm{p}}$ については，国土交通省の検討結果より 1.3 とし ${ }^{200}$, $R_{\mathrm{t}}$ については，死者率 $=2.6 \%$, 負傷者率 $=14.2 \%$ ，重傷 者率 $=5.6 \%$ を仮定した ${ }^{10)}$.

\section{（5）全体的な算定結果と考察}

道路損壊に伴う社会的損失の算定結果を図 -4 , 図-5 に示寸. 図-5 に示した損失額の内訳については，施工 延長 $50 \mathrm{~m}$ のケース（条件 $1-\mathrm{B}, 2-\mathrm{B}$; 参考: 表-2) の夕について示した．構造物が高いときほど，構造物の 延長距離（復旧区間に相当）が長いものほど，復旧に要 する時間が長くなるために，災害復旧費，時間損失，走 行損失および人的損失からなる総損失費は大きくなる. 


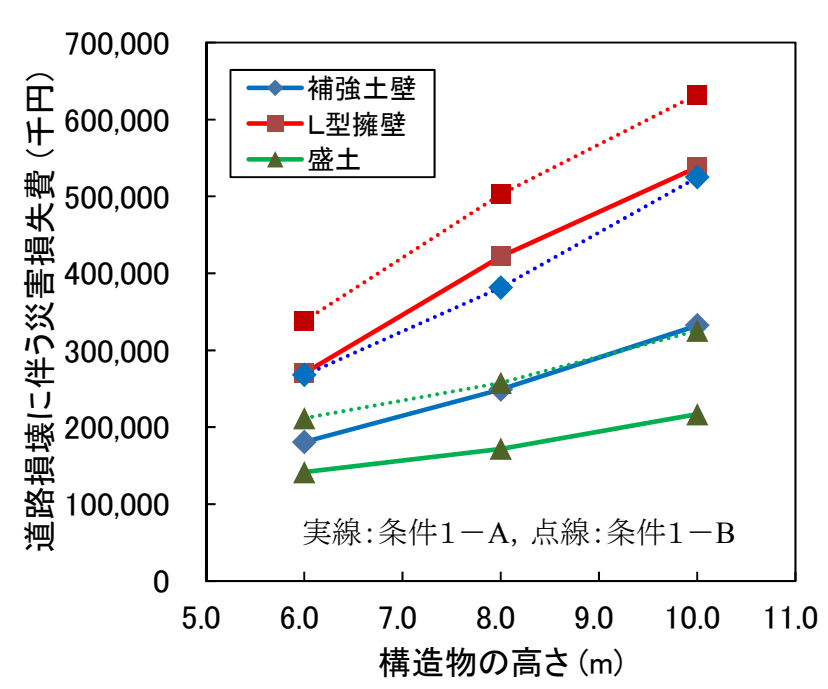

（a）条件 1-A，1-Bに対する算定結果

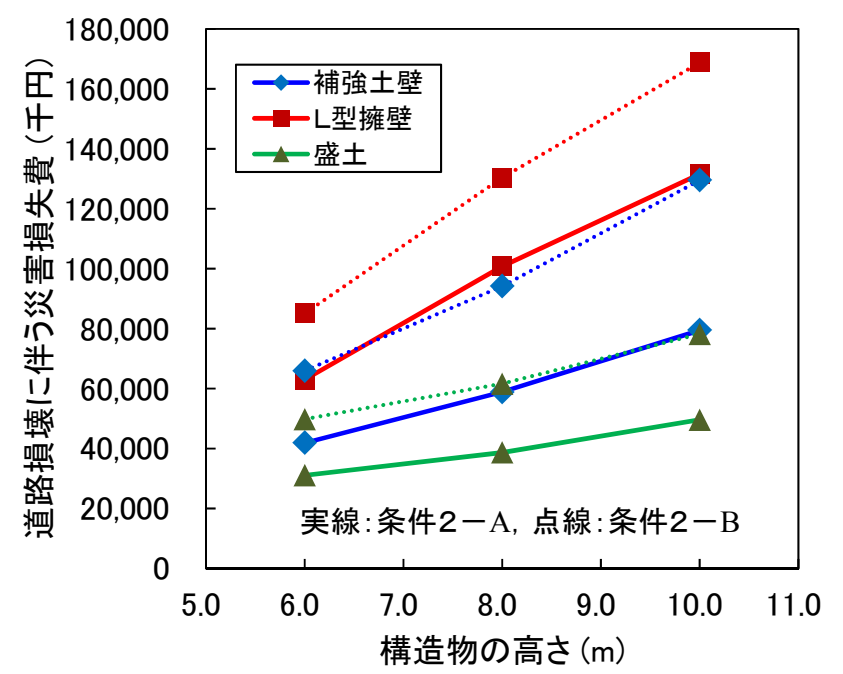

(b) 条件 2-A，2-Bに対寸る算定結果

図-4 4つのケース(表-2)に対する災害損失費

構造物の種別で比較すると, 盛土, ジオグリッド補強土 壁，L 型擁壁の順に損失費が大きくなる．この傾向は， 交通量 (条件 1 と条件 2 ) で変わらない. 損失額の内訳 は, 迂回損失の中の時間損失が最も大きく, 条件 1 (交 通量・大）では時間損失の次に大きな額の走行損失の 3 〜4倍となっている. 条件 2 (交通量・小) では条件 1 と比較して迂回損失費が小さくなるため, 総損失費に占 める災害復旧費の割合は高くなる. 交通量の多い路線で は，損壊し難い構造物を選定することは当然であるが， 復旧が容易な構造物を選定することが社会的損失を抑制 することにつながる. 一方, 交通量の少ない路線では, 災害損失費の割合が小さくなることから，建設費の小さ い構造物の選定が重要にある. ジオグリッド補強土壁は いずれの要求に対しても，うまく適合する構造形式であ るといえよう。

以上の選定結果をまとめ，式(1)で LCC を算定した結 果を図-6 に示寸. 構造物毎の LCC は, 交通量の大小
費用 (千円)

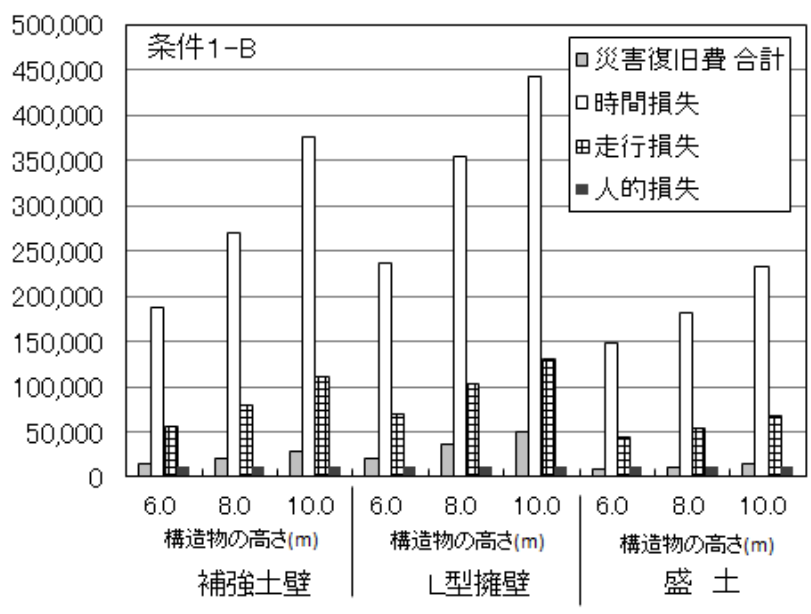

(a) 条件 $1-\mathrm{B}$ に対する算定結果

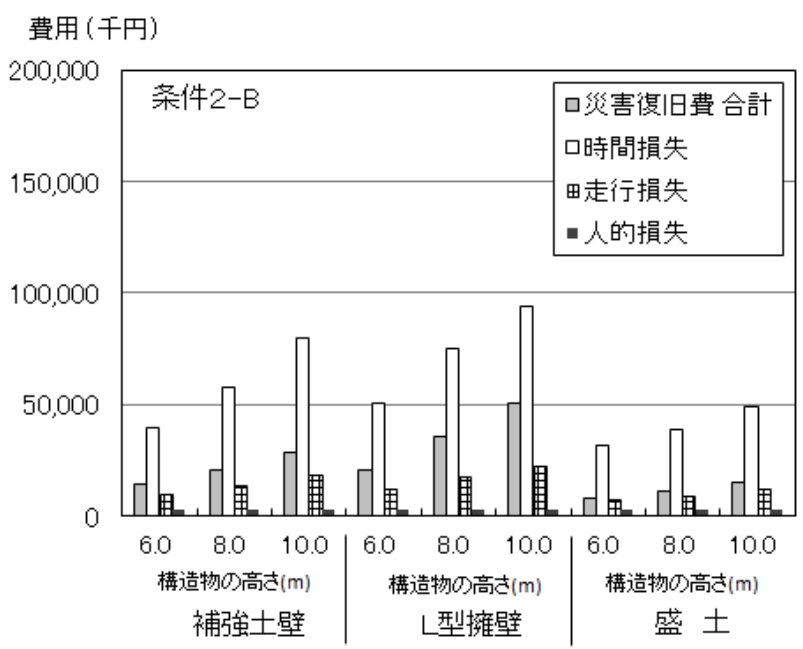

(b) 条件 $2-\mathrm{B}$ に対する算定結果

図-5 構造物の延長 $50 \mathrm{~m}$ の場合の苂害損失費の内訳

（条件 1 および 2 ）に関わらず，ジオグリッド補強土壁 が最も小さく，次いで L 型擁壁，盛士の順に大きくな る. 破壊確率を考慮しない災害損失費では，L 型擁壁の ほうが盛土より損失（コスト）が大きくなるが，LCC で比較すると盛土のほうが高くなる. 盛土は構造物の高 さが高くなると破壊確率が大きくなるため，LCCが急激 に大きくなる．このために，LCC で評価する上では L 型擁壁のほうが優位性の高い結果になった。 なお，高さ 6mのケースでは，L型擁壁と盛土の LCC は同程度であ るものの，被災した場合における復旧までの日数は盛土 が 10 日以上短いことから, 盛土のほうが優位と判断さ れる. ジオグリッド補強土壁は, 交通量の多少や構造物 の高さの違いに関わらず，LCCが相対的に小さく，工法 選定において L 型擁壁や盛土より優位な構造物である と評価できる.

土構造物の分野では，LCCの導入は十分ではない，限 られた投資で安心・安全を確保するためには，どうして も本文に示したような意思決定のための方法論が必要に 


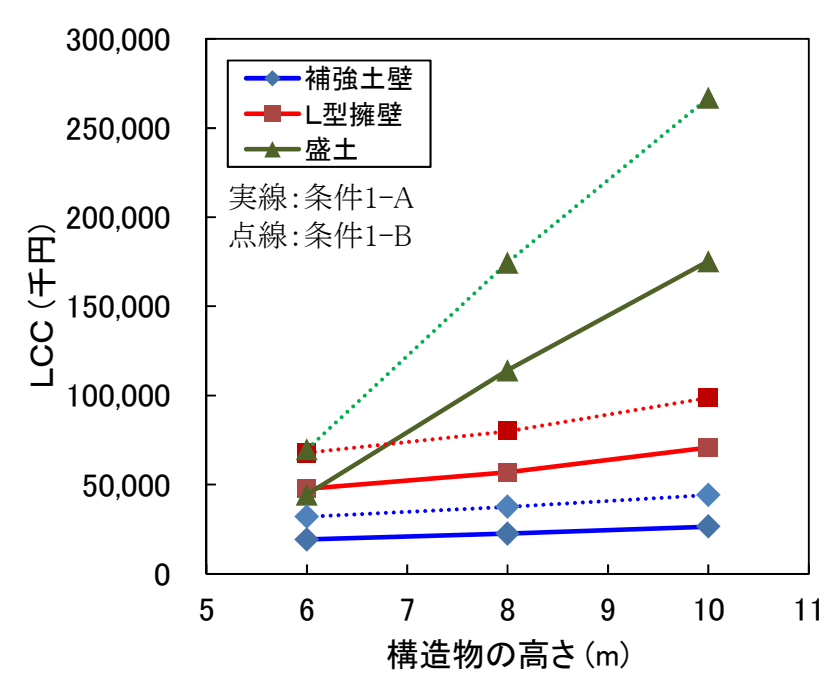

(a) 条件 1-A，1-Bに対する算定結果

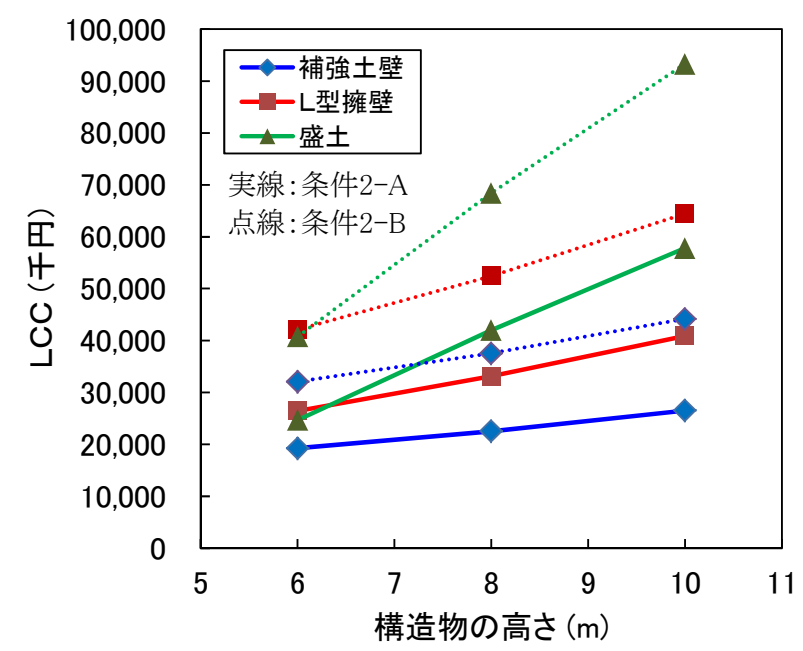

(b) 条件 2-A，2-Bに対寸る算定結果

図-6４つのケース(表-2)に対するLCCの算定

なってくる. 従来このような方法は，技術自体に熟知し ていない他分野の専門家に行われることが多かった。 今 回示したような取り組みを継続的に行い，良い技術が社 会で選択される仕組みづくりに貢献する必要があると考 えられる.

\section{4. まとめ}

本論文の内容をまとめると以下のとおりとなる.

(1) 構造物の損壊に伴う不便益を考慮したジオグリッド 補強土壁のライフサイクルコスト $(L C C)$ を, 初期 建設費，維持管理費，地震による災害損失リスクの 和で評価する方法を提案した，復旧費に加え，時間， 走行，人的損失費を考慮できるように従来の LCC 評 価法を拡張したため, 構造物の重要度を考慮した LCCの算定が可能になった.

（2）ジオグリッド補強土壁，L 型擁壁，無補強盛土の 3
種類に対して解析を行った．構造物の高さが $\mathrm{H}=6.0$, 8.0,10.0 m を対象に計算を行い，ジオグリッド補強土 壁は交通量の大小や復旧区間の長さに関わらず LCC が最も小さくなることを明らかにした.

想定する条件によって LCC の算定結果は異なる．次 のステップとして LCC の算定精度の向上，低減のため の技術開発が挙げられるが，これについては詳細な感 度解析が必要である. 以上については今後の課題とし たい.

謝辞 : 本研究の成果は, IGS 日本支部技術委員会第5 ステージ （2010-2012）の成果に基づく. 支部の皆様にここに記して感謝 の意を表したい．また，この論文は 5 名の著者によるものであ るが，その内容には委員会での議論が大いに役立った. ここに 委員名簿を明記することで，各委員の貢献に敬意を払いたい． 委員長 : 宮田喜壽（防衛大学校）, WG1（経済性）主査 : 大 野孝二(飛島建設)，WG2（健全性）主査 : 篠田昌弘（鉄道 総研）, WG3（材料）主查：竜田尚希（前田工緎），小浪岳 治（岡三リビック），原 隆史（岐阜大），原健二（太陽工 業），米澤豊司（鉄道・運輸機構），中村洋丈（高速道路総合 技術研究所），中島 進（鉄道総合技術研究所），幹事：弘中 淳市 (三井化学産資)。また第 2 著者は文部科学省科学研究費 補助金基盤研究(B) 24360195 の助成を受けました. 記して感謝 の意を表します。

付録 : 補強土壁・L型擁壁・盛土の信頼性解析法

各破壊モードの破壊確率 : $P\left(\mathrm{E}_{\mathrm{j}}\right)$ は, Hasofer and Lind ${ }^{21)}$ により提案されている FORM (First Order Reliability Method) を基本に計算する。 この解析法は，各破壊モードに対す る構造物の安定性を，以下のとおり， Z $>0$ で安定， $Z \unlhd 0$ で破壊となるように性能関数：Z(X)を用いて表現し，P $\left(\mathrm{E}_{\mathrm{i}}\right)$ をZが負になる確率として算定する.

$$
Z=g(\mathbf{X})
$$

ここで, $\mathbf{X}=\mathbf{X}\left(x_{1}, x_{2}, \cdots, x_{\mathrm{n}}\right)$ は設計確率変数である。一連 の解析では, まず最小安全率となる破壊モードを求め, 次に, その状態に対して, 式(付 2)で定義される信頼性 指標 $\beta$ を計算する. その後, 標準正規分布関数の逆関数 を用いて $P\left(\mathrm{E}_{\mathrm{i}}\right)$ を計算する.

$$
\beta=-\frac{(\partial Z / \partial \mathbf{X})_{*}{ }^{\mathrm{T}}\left(\mathbf{X}^{*}-\boldsymbol{\mu}_{\mathbf{X}}\right)}{\sqrt{(\partial Z / \partial \mathbf{X})_{*}{ }^{\mathrm{T}}(\partial Z / \partial \mathbf{X})_{*}}}
$$

ここで， $\mathbf{X} *$ は性能関数を満足する確率変数のベクトル $\left(x_{1}{ }^{*}, x_{2}{ }^{*}, \cdots, x_{\mathrm{n}}{ }^{*}\right), \mu_{\mathrm{X}}$ は各設計確率変数の平均值である.

破壞モードについては，ジオグリッド補強土壁に対し ては図-1を，L型擁壁に対しては付図-1を，盛土に対し ては「のり先をとおる円弧すべり」を想定し，それぞれ に現行の設計法で用いられている設計モデルを性能関数 として破壊確率を算定した。性能関数の詳細は文献4)を 参照されたい．補強土壁と盛士の解析パラメータについ ては3 (1)で述べたとおりである. L型擁壁については付 表一の定数を用いた. 


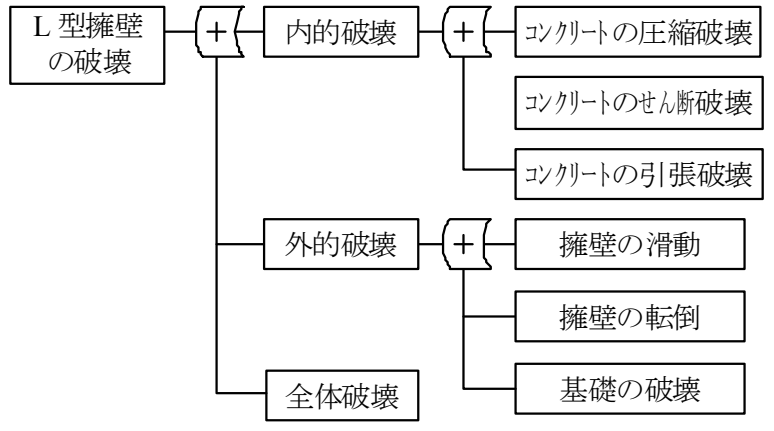

付図-1Ｌ型擁壁の破壊モード

\begin{tabular}{|l|l|}
\multicolumn{1}{|c|}{ 付表-1 コンクリートと鉄筋の解析定数 } \\
\hline & 平均, 変動係数 \\
\hline コンクリートの圧縮強度 & $30.0 \mathrm{~N} / \mathrm{mm}^{2}, 10 \%$ \\
\hline コンクリートのせん断強度 & $1.0 \mathrm{~N} / \mathrm{mm}^{2}, 10 \%$ \\
\hline 鉄筋の引張り強度 & $3000 \mathrm{~N} / \mathrm{mm}^{2}, 5 \%$ \\
\hline
\end{tabular}

\section{参考文献}

1) 総務省行政評価局: 社会資本の維持管理及び更新に関す る行政評価・監視結果報告書, 2012 .

2) 国土交通省大臣官房官庁営繥部 監修, 建築保全センター 編集・発行: 建築物のライフサイクルコスト(平成 17 年 版), 経済調查会, 2005.

3) 日本橋梁建設協会: 橋梁LCC ソフト, 2011.

4) 宮田喜壽, 篠田昌弘, 小浪岳治, 大野孝二, 米澤豊司, 弘中 淳市: ジオグリッド補強土壁のライフサイクルコストの 算定法, ジオシンセティックス論文集, Vol.25, pp.177-182, 2010.

5) 大野孝二, 宮田喜壽, 小浪岳治, 弘中淳市, 金子智之: ジオ グリッド補強土壁のライフサイクルコスト算定を目的 とした初期建設・維持管理・災害復旧費の標準的算定 法, ジオシンセテイックス論文集, Vol.25, pp.183-188, 2010.

6) 篠田昌弘, 宮田喜壽, 米澤豊司, 弘中淳市: 無補強盛土と
補強盛土のレベル II 地震時ライフサイクルコストの算 定, ジオシンセティックス論文集, Vol.25, pp.189-196, 2010. 7) 宮田喜壽, 篠田昌弘: ジオシンセティックス補強土壁の システム午長性を考慮した信頼性解析法, ジオシンセテ イックス論文集, Vol.24, pp.269-274, 2009.

8) 大津宏康, 松山裕幸, Nutthapon SUPAWIWAT, 高橋健二: 斜面対策工の性能低下過程の不確実性を考慮した LCC 評価, 土大学会論文集 $F$, Vol.62, pp.405-418, 2006.

9) 国土交通省道路局都市・地域整備局: 費用便益分析マ二 ュアル, 2008 .

10) 大阪府: 大阪府地震被害想定調查 報告書, 1997.

11) 土木研究センター: ジオテキスタイルを用いた補強土の 設計・施工マニュアル, 2002.

12) 日本道路協会: 道路土工一推壁工指金十, 2012.

13) 日本道路協会: 道路土工一盛士工指針, 2010.

14) 全日本建設技術協会: 土木構造物標準設計一第 2 巻 擁壁 類, 2000 .

15) 壇一男, 神田順: 上下限を有する極值分布を用いた地震 危険度解析，日本建築学会構造系論女報告集, 第 363 号, pp.50-56, 1986.

16) 国土交通省: 土大工事標淮積算基蕉書(平成 21 年度版), 2009.

17) 福井県土木部道路建設課：平成 17 年度全国道路交通情 勢調查（道路交通センサス）一般交通量調查報告書， 2006.

18) 国土交通省 道路事業の評価手法に関する検討委員会: 平 成 20 年度第 4 回委員会 資料 2 走行時間短縮便益の計算 方法について, 2008.

19) 日本交通安全協会: 交通の教則(普及版), 2012.

20) 国土交通省 道路事業の評価手法に関寸る検討委員会: 平 成 20 年度第 4 回委員会 : 参考資料 1 時間価值原単位お よび走行経費原単位の算出方法, 2008.

21) Hasofer, A.M. and Lind, N.C. An exact and invariant secondmoment code format. Journal of the Engineering Mechanical Division, ASCE, Vol. 100, pp.111-124, 1974.

\title{
LIFE CYCLE COST ANALYSIS OF GEOGRID REINFORCED SOIL WALL CONSIDERING SOCIAL COSTS BY STRUCTURAL FAILURE
}

\author{
Koji OHNO, Yoshihisa MIYATA, Masahiro SHINODA, Takeharu KONAMI, \\ and Jun-ichi HIRONAKA
}

\begin{abstract}
The life cycle analysis method is proposed for geogrid reinforced soil wall. The proposed method evaluates life cycle cost as total cost of initial cost, maintenance cost and seismic risk. This paper shows the standard evaluation method of the seismic risk which is a product of failure probability and seismic disaster costs. Based on the proposed method, LCC of geogrid reinforced soil wall, L-shaped RC wall and no-reinforced embankment were compared. It is cleared that LCC of the geogrid wall is the lowest in spite of traffic volume and structure length. Content of this paper is from achievement produced by Technical Committee: Stage 5 established in IGS Japan chapter (2010-2012).
\end{abstract}

KEYWORDS: reinforced soil walls, life cycle cost, risk, social costs 